UDC 655.05

\title{
TRENDS OF TRANSFORMATION OF PRINTED PRODUCTS
}

\author{
A. S. Morozov, A. V. Kravchenko \\ National Technical University of Ukraine \\ "Igor Sikorsky Kyiv Polytechnic Institute", \\ Publishing and Printing Institute, 1/37, Yanhel St., Kyiv, 03056, Ukraine
}

The researches of tendencies of introduction of electronic edition and replacement of material on the basis of analysis and forecasts of experts, the analysis of the transformation of the printed edition, the possibilities of electronic, the emergence of new technologies that influence the economy and the importance of the book in everyday life are carried out.

Progress is not in the city, and it is very good. We only need to learn how to relate the latest technology to already existing resources. So the e-book and the paper will coexist in the everyday life of people, complementing each other.

Keywords: electronic publication, material carrier, internettize, modern technologies, expert forecasts.

Formulation of the problem. One of the current problems in the paper industry market is the replacement of some existing paper products with their electronic copies. Many experts express their opinions and forecasts regarding the replacement of printed publications by electronic media. All of them have their own arguments.

The electronic edition has wide opportunities, therefore it gradually enters our lives. Today, internetisation is rapidly gaining momentum in various fields, but not all editions can be replaced by electronic ones. That is why there are discussions between experts about the complete transition to electronic publication and the waiver of material. The press is also developing and undergoing transformation. There is a question to determine the future of print production as a material carrier and electronic.

Analysis of previous research and publications. Recently, the World Intellectual Property Organization, which is one of the UN agencies, has announced the exact date of the death of paper publications. In an interview with the Swiss edition (incidentally, still paper) Tribune de Geneve, director of the organization Francis Harry stated that the print press would eventually disappear by 2040, and in the United States even earlier - by 2017. «This evolution is neither good nor bad, it's inevitable,» he explained. The arguments of the professor differ little from the arguments of many other experts in the media industry: the total «internetisation» of society, the massive transfer of media to the virtual plane, and the higher demand for books and the press on digital media. However, this does not mean that the print press will disappear as a phenomenon, rather it transforms. Almost a year before the interview, the famous futurist and business strategist Ros Dawson, formulating an almost identical forecast, also spoke about the 
transformation of print media into something new. For example, the development of flexible electronic paper will allow you to get a traditional newspaper in form, but with enormous opportunities.

About the search for paper media new forms of existence were also discussed at the IV Annual Conference of Publishers and Media Distributors in Kyiv. Director of Europe AIM Group, the author of the first German newspapers and the Internet «Newspapers Online: New Ways to Advertisers and Readers», author of the world's first analytical study on digital versions of traditional newspapers, media expert Katya Reifler predicts that in the immediate future Ten years of print media may be reduced by $50 \%$ or more. That is why the expert advises to develop their «digital profit» now.

«I do not think that the print press will die so soon, because readers are still trying to read it. However, publishers will not be able to afford to print. Already today we are seeing a decrease in the number of outputs and a decrease in the circulation of paper editions, «Katya Reifler told The Day.

The expert advises print media publishers to try their hand in the digital industry today. «You must take care first of all about the content, about the values that you give to readers. If your publication takes into account the needs and interests of your audience, then people will read you on any medium - both on paper and electronic, «Mrs. Reifler is confident.

According to the expert, the current version is unfortunate when the electronic version of the paper is an exact copy of the paper. «The digital version should be different from the paper. He must focus on other priorities and methods of work, be interactive, be able to instantly raise interest in himself, create reactions, encourage discussion. Also, the electronic edition should be extremely operative in the presentation of hot news, while paper can wait and subsequently deeply develop the topic «, - explained Katya Reifler to» Day «. Also, she says, the publication should have separate journalists for each version.

The European expert's advice in Ukraine will have his own reservations. The percentage of Internetisation here is still insignificant compared to European countries, even post-Soviet. For example, in Estonia, Internetisation is approaching $100 \%$. And in Ukraine penetration reaches about $35 \%$. It is clear that in such conditions, the final transfer to the network of major print media can not be said. And, judging by the disappointing processes taking place in the market of providers (so to speak, not without the state's participation), the prospects for further internetization are not very encouraging. To achieve such indicators, as in Estonia, there is a need for state support and an understanding of why this is important. Internetisation is transparency, «airing» and democratization [1].

Aim of the study. The aim of the research is the question of the coexistence of an electronic and paper book, taking into account the development of technologies, their impact on the economy and the significance of the book in everyday life.

Presentment of the main material of the research. In its original form, an e-book declared itself in the United States and Japan in the early 90's of the last century. In a short time, it has become the strongest strategic challenge in the publishing industry. 
Her appearance is even compared with the invention of writing and printing. It is possible to evaluate in different ways the advantages, risks and threats introduced by the digital culture, but it does not go away from its reality. To perceive the electronic book as a newfangled and fast-moving banality would be too lightweight and professionally incompetent. More rational - to admit that it is one of the most characteristic artifacts of a globalized information world [2].

The publishers have already made sure that the Internet has a "strong strategic significance" for them [3], with the European, American and Japanese ones (in this country there is an association of publishers of the e-book). True, most of them are still working on the prospect, because only some can "really make money in electronic publications" [3, p. 220]. Ukrainian publishers will first have to understand this, and then decide on the fundamental development strategies: focusing only on the printed book or, without leaving work with it, developing an e-book and hybrid products, or perhaps only an e-book; to form the actual client environment in the network, to enter into direct relations with buyers or to continue to use the distribution capabilities of partners, which often act as competitors. Obviously, the new strategic context will be formed on the basis of autonomous and convergent models, the relationship of which will depend on the competences, opportunities, ambitions, successful and bitter lessons. So far, most publishing co-authors perceive electronic literacy as alien to their mentality and aggressive element, business necessity, but not as a space of professional passions and preferences. Therefore, specialists in the Ukrainian publishing industry do not yet have a comprehensive understanding of the problem and even imitative strategies in dealing with electronic publications. To date, no answers have been found on the most basic questions: how to digitize published books, archival, library funds, who and on what principles should do this; what technologies, formats to use in the preparation, promotion and sales of electronic novelties; what will be the future competitive environment when domestic content will actually compete with digital products all over the world.

The best chances to get used to the e-book market are publishers who will not sit at the start and will not chase the heads down without thought. Indeed, much will depend not only on the quality and effectiveness of their innovative efforts, but also on the trend in reading. So far, various operational information has led to ambiguous reflections. One of her streams emotionally reports about the triumphal echo of the world of space. However, statistics, although totally objective information is not available in any country for various reasons, tune in to more lenient reactions: despite an annual three-fold increase in sales, they only surpassed one percent of the book market by far. The only exception is the USA, where in 2008 the Internet became the largest distribution channel for publishing products $(23 \%)$, one percent ahead of networked bookstores, and continues to build on its potential. In 2009, every fifth resident there preferred an e-book, refusing to purchase paper. In 2010, sales of electronic content in this country amounted to $\$ 1$ billion. (7.2\% of the book market). This was largely due to Amazon's global leader, whose digital book has surpassed the printed paperback. Dynamic electronic book publishing is also in Japan, European countries. It looks like serious attention to her and 
inexperienced Russian publishers try their hand. In Ukraine it is possible to notice that the embryos of her are skinny. So far, this market has not yet gained self-sufficiency, and the latest technologies and products have not become decisive on it. Organizationally, technologically, and communicatively, it is not everywhere built on fully-fledged own strategies, since its operators are mostly guided by the needs, interests, and dynamics of the demand for buyers of paper books [6].

But even if in the near future books, magazines, newspapers and other printed products will replace their electronic copies, paper products can not be completely thrown out of our lives. She has been, is and will remain in everyday life for many years. There are many reasons for this and there are many discussions.

First, even if electronic books are introduced into life, the need for their use will not disappear completely. Currently, not every electronic carrier can replace, for example, a tutorial. And even if this is being implemented now for senior students and students, preschoolers and junior children will still have to work on paper textbooks, since the excessive holding of an electronic screen damages the health of even an adult, not to mention the young organism of children. There will also be quite a significant demand for notebooks, notebooks, notebooks, diaries and other school supplies that are unlikely to be consumed. Albums, wattans, paper for artistic use are also not going anywhere. Promotional paper products, such as brochures, booklets, posters, posters, leaflets and leaflets, will continue to occupy a certain niche in people's lives.

So, we can say that completely printed products will not disappear from our life. A certain replacement of some books on the electronic completely does not exclude their circulation in our lives. They simply will become more rare, qualitative and exclusive phenomenon than before. Reducing the number of printing products at the publisher will allow you to allocate a larger share of capital to the purchase of higher quality paper, which will make the book a unique and more expensive product.

Electronic technologies also penetrated the distribution activities, changing the ways of reporting books to target audiences, the structure of their sales. As the space of strategic initiatives in the electronic sphere, book distribution networks and independent bookstores are considered. Over time, they will become cultural information, multimedia centers. However, a self-sufficient e-book market with rules that are understandable and acceptable to all its members has not yet been created, so the scale of traditional and electronic book flows is not commensurate.

With the increase in the number of people who are inclined to seek the necessary information through the Internet, expanding the presence of online publishers becomes one of the key factors in their success and a conceptual source of strategies. Their configuration will depend on interests, capabilities and probably will combine: marketing researches of target audiences, online promotion (online catalogs), networking communities, various methods of communication with their participants, open discussion of books, network book clubs, "guerrilla" and "viral" promotions, the development of direct sales. The use of the latest communication technologies is a prerequisite for the publisher to replace the "give-forward" strategy to the "promote-send" strategy, which significantly reduces the risks of doing business [5]. 
With the advent of electronic technologies, in particular the Internet, mankind has discovered many new opportunities, some of them even replaced the need for certain things. For example, with the emergence of almost electronic and social networks, the need for correspondence sharply and significantly dropped, but still did not disappear completely. Receiving a letter, people are now more happy than the message on the network. After all, the letter now became a rare and exclusive phenomenon, forcing people to feel that they are holding something almost rosy in their hands. So with a book, the same thing can happen if the plan for replacing their electronic versions is still to come true.

But there are many prerequisites that need to be addressed. In particular, economic ones. After all, the reduction of the needs of people in books may leave many publishers out of work, will reduce staff, increase unemployment. Of course, there will be some demand for employees in the area of creating electronic books, audio books, making PocketBook, Kindle, iRiverStory, Lbook, eReader and other electronic media, designing and creating online newspapers, magazines and more. But these positions will attract younger specialists with some knowledge and experience in this modernized industry, and people who have given a large number of years of work to printing companies and publishing houses will not be left. Re-training will cost a lot of money and money, it is unlikely that the state will be able to provide such an opportunity, and not all employees will want to re-retrace another specialist to stay in the industry, albeit in electronic, polygraphy. In addition, electronic readers, as they are now called, are quite expensive, and not every citizen of the middle class can afford them, which also restricts people in their use, and forces them to remain true to the paper carriers of information.

Today, few people take responsibility to assert what architecture and the landscape of the publishing industry will be in the future, because everything here is developing especially dynamically, quickly giving birth and dying. In spite of this, intellectual inability, technological and organizational failure, investment failure, incorrect choice of models of participation in this conveyor can become equivalent to strategic failures and business self-destruction.

Forecasts signal and practice confirms the special attractiveness for electronic book publishing reference-encyclopedic, vocabulary, scientific, educational, applied books. Their use is mainly related to the satisfaction of informational, cognitive needs. Screen reading may be quite suitable for such a case. Therefore, it is in these segments that tangible washing of streams of printed products is possible.

The reasons for such predictions are called: an increase in the number of young people in school classes and classrooms of higher educational institutions, in the cognitive culture of which is based on on-line reading; aggressiveness focused on electronic communications business; the injection of specially selected information, which in critical volumes and purposefully constructed ad formulas («In the school with one textbook», «Every student in the computer», «Bookhead in each hatch», etc.) is converted into social fashion. These trends also feed on the predictions that, in the field of electronic literacy, business interests will focus not only on the content but also on the means, 
technologies of operating it. Exactly the activities in this area will bring the highest profits, hence, apparently, will face a variety of competitive challenges, social risks, against which the alleged degradation of publishing, the destruction of the printing, distribution of its segments, the classical library system will not be perceived as the most critical problem. It will be important to realize that the backlog in technology is the cause of defeats in the global struggle for information and intellectual, business space. After all, modern technological competitions - not only the passion of «silicon (silicon) valleys», the clondike for electronic «micuchers» and architects of «rider pyramids», but also tests of competitiveness of the country. Though recent events lead to reflections on how justified these competitions and whether they will cause unreasonable losses to humanity [4].

Conclusions. But, to say the least, it is all just theory, and now it is almost impossible to foresee the development of future events and transformations, and their subsequent consequences in the economy and in everyday life. It is only possible to say exactly that the book, as such, was, is, and will remain desirable for another decade. And the emergence of new technologies will only lead to some transformation in the printing industry. Progress is not in the city, and it's very good. We only need to learn how to relate the latest technology to already existing resources. So the e-book and the paper will coexist in the everyday life of people, complementing each other. But all this is just some speculation. And finally to say how it will not be possible now. We can only hope that everything that is not done will be done for the better. And we will be able to find the right way to resolve all issues.

\section{СПИСОК ВИКОРИСТАНИХ ДЖЕРЕЛ}

1. Semenchenko M.. Daily All-Ukrainian Newspaper «Day».

2. Ivanov V. Modern computer technologies and means of mass communication: aspects of application. Kiev: IZMN, 1996. 180 p.

3. Alt K. Book on the screen: product and sales strategy. Interview with Zigrid Lesch, K. Alt. Modern book publishing: a collection of materials on the project «Improvement of professional skills of publishing specialists of the countries of Eastern Europe and Central Asia, 2009-2011». M., 2010. P. 209-225.

4. Hardison Jr. O. B. Disappearing Through the Skylight: Culture and Technology in the Twentieth Century (New York: Penguin, 1989). P. 264.

5. Dane G. Production and economic optimization of enterprise management, Modern book publishing: a collection of materials on the project «Improvement of professional skills of publishing industry of countries of Eastern Europe and Central Asia, 2009-2011». M., 2010. P. $133-137$.

6. Teremko V. Strategic tests by e-book. Bulletin of the Book Chamber. 2011. P. 10-14.

\section{REFERENCES}

1. Semenchenko, M. Daily All-Ukrainian Newspaper «Day» (in English).

2. Ivanov, V. (1996). Modern computer technologies and means of mass communication: aspects of application. Kiev: IZMN (in English). 
3. Alt, K. (2010). Book on the screen: product and sales strategy. Interview with Zigrid Lesch, K. Alt. Modern book publishing: a collection of materials on the project «Improvement of professional skills of publishing specialists of the countries of Eastern Europe and Central Asia, 2009-2011». M., 209-225 (in English).

4. Hardison Jr., O. B. Disappearing Through the Skylight: Culture and Technology in the Twentieth Century (New York: Penguin, 1989), 264 (in English).

5. Dane, G. (2010). Production and economic optimization of enterprise management, Modern book publishing: a collection of materials on the project «Improvement of professional skills of publishing industry of countries of Eastern Europe and Central Asia, 2009-2011». M., 133-137 (in English).

6. Teremko, V. (2011). Strategic tests by e-book: Bulletin of the Book Chamber, 10-14 (in English).

doi: 10.32403/0554-4866-2019-1-77-78-85

\title{
ТЕНДЕНЦІЇ ТРАНСФОРМАЦІЇ ДРУКОВАНОЇ ПРОДУКЦІЇ
}

\author{
А. С. Морозов, А. В. Кравченко \\ Національний технічний університет України «Київський політехнічний \\ інститут імені Ігоря Сікорського», Видавничо-поліграфічний інститут, \\ вул. Янгеля 1/37, Київ, 03056, Україна \\ nastyakravchenko1786@gmail.com, \\ morozov.and@ukr.net
}

Здійснено дослідження тендениій вровадження електронного видання та заміщення ним матеріального. Дослідження проведено на основі аналізу та прогнозів експертів, аналізу трансформації друкованого видання, можливостей електронного, появи нових технологій, які впливають на економіку та значення книги у повсякденному житті. Багато залежатиме не лише від якості та результативності інноваційних зусиль, а й від тендениії у сфері читання. Поки що різноманітна оперативна інформація спонукає до неоднозначних роздумів. Один із ї̈ потоків емоційно рапортує про тріумфальну ходу електронної книги просторами свіму.

Певна заміна деяких книжок на електронні повністю не виключає їх обіг у нашому житті. Вони просто стануть більш рідкісним, якісним та ексклюзивним явищем, ніж раніме.

Прогнози сигналізують і практика підтверджує особливу привабливість для електронного книговидання довідково-енциклопедичної, словникової, наукової, навчальної, прикладної книг. Використання їх пов'язане переважно із задоволенням інформачійних, пізнавальних потреб. Екранне читання може бути иілком придатним для такої справи. Тому саме в циих сегментах можливе відчутне обміління потоків друкованих продуктів. 
Прогрес не стоїть на місті, і ие дуже добре. Потрібно лише навчитися співвідносити новітні технології з уже існуючими ресурсами. Тож електронна книга та паперова будуть співіснувати у повсякденному середовищі життя людей, взаємодоповнюючи один одного. Можливо точно сказати, щчо книга, як така, була, $\epsilon$, і залишиться бажаною ще не один десяток рік.

Ключові слова: електронне видання, матеріальний носій, інтернетізація, сучасні технологіі, прогнози експертів.

Стаття надійшла до редакиії 05.02.2019.

Received 05.02.2019. 